\title{
KRITIK SOSIAL DALAM PUISI NYANYIAN ANGSA KARYA W.S RENDRA: TINJAUAN SOSIOLOGI SASTRA
}

\author{
Linda Ayu Darmurtika \\ Dosen Program Studi Pendidikan Bahasa dan Sastra Indonesia \\ FKIP Universitas Muhammadiya Mataram \\ Lindaayu_darmustika@yahoo.com
}

\begin{abstract}
ABSTRAK
Puisi Nyanyian Angsa karya W.S Rendra bertemakan penolakan tokoh utama/Maria dalam lingkungan sosialnya. Penelitian ini bertujuan untuk mendeskripsika bentuk-bentuk penolakan yang dialami oleh Maria, seorang perempuan yang bekerja sebagai wanita malam (pelacur) dengan mengkajinya menggunakan pendekatan sosiolagi sastra dengan memokoskan penelitian pada aspek agama. Kritik sosial dalam puisi ini kental terlihat, terutama yang dilakukan oleh pastor. Puisi Nyanyian Angsa mengandung pesan dan kritik terhadap agama terlihat melalui alur dan penokohan tokoh Marai dan pastor. Agama idealnya membawa penganutnya ke arah yang lebih baik, namun Marai sebagai umat yang beragama mendapatkan perlakauan yang tidak baik dalam lingkungan sosialnya, karena statusnya sebagai wanita malam. Agama dalam kajian ini diartikan sebagai sebuah ajaran yang dipegang oleh Maria yang tidak mencerminkan sikap seseorang yang beragama, yang senantiasa bersabar dalam kondisi/keadaan ekonomi yang tidak mendukung.
\end{abstract}

Kata kunci: kritik sosial, agama, sosiologi sastra

\section{PENDAHULUAN}

Puisi sebagai salah satu media dalam menyampaikan ide atau kritik terhadap permasalahan yang terjadi di dalam masyarakat. Puisi adalah salah satu dari tiga gendre sastra yang merupakan karya sastra indah, mampu menggetarkan jiwa, yang berbentuk sajak, penulisannya terikat pada aturan tertentu. Dalam KBBI (2008:903) puisi adalah ragam sastra yang bahasanya terikat oleh irama, matra, rima, serta penyusunan larik dan bait. Secara itimologi istilah puisi berasal dari bahasa Yunani poeima "membuat" atau poesis "pembuatan" dan dalam bahasa Inggris disebut poem atau poetry-puisi diartikan "membuat" dan "pembuatan" karna lewat puisi pada dasarnya seorang telah menciptakan suatu dunia tersendiri, yang mungkin berisi pesan atau gambaran suasana-suasana tertentu baik fisik mupun batiniah, menurut Aminuddin, 2011:134. Menurut Hudson (dalam Aminuddin, 2010:134) puisi adalah salah satu cabang sastra yang menggunakan kata-kata sebagai medi penyampaian untuk membuahkan ilusi dan imajinasi, seperti halnya lukisan yang menggunakan garis dan warna dalam menggambarkan gagasan pelukisnya.

Puisi Nyanyian Angsa karya W.S Rendra bertemakan penolakan tokoh utama/Maria Zaitun dalam lingkungan sosialnya, karena Maria sudah tidak menguntungkan dan tidak bisa menghasilka uang menurut germonya. Selain sakitsakita, Maria juga sudah tergolong tua 
sebagai seorang pelacur. Maria diusir dari tempat kerjanya dan dia berjalan tanpa membawa kopernya mencari seorang dokter. Maria mendatangi seorang dokter di tempatnya praktek dan tanpa menunggu antria Maria disuruh lebih dulu masuk ruangan dokter karena para pasien jijik melihat tubuh Maria dan baunya yang mengganggu. Maria hanya disuntik vitamin C padahal sedang kesakitan karena luka bernanah di bagian-bagian tubuhnya. Sang dokter hanya memberika injeksi, karena Maria tidak akan mampu membayar lagi. Dokter tersebut mengatakan kepada perawatnya, kasi injeksi vitamin C saja, karena dia tidak akan sanggup membayarnya, hutangnya saja masih ada apalagi sekarang dia sudah tidak punya apaapa. Marai mendapat penolakan di tempat berobat karen penyakit sipilis yang dideritanya.

Maria kembali berjalan dan saat itu siang hari, ia mencari sebuah gereja untuk menemui seorang pastor karena ingin mengaku dosa. Sesampainya di gereja ia hanya bertemu koster dan dia diberitahu bahwa pastor sedang makan siang dan pastor tidak bisa diganggu. Namun Maria mengatakan bahwa dia ingin sekali bertemu pastor. Sambil memperhatikan tubuh Maria yang berdebu dan berbu koster segera memanggil pastor, tetapi tidak mengizinkan Maria masuk. Setelah bertemu pastor, Maria pun tidak mendapatkan perlakuan yang layak, sama hal nya ketia dia menemui sang dokter. Seperti orang-orang yang menunggu antrian di tempat praktek dokter yang jijik melihat badan Maria, sang pastor pun begitu. Memandang sinis Maria karena kondisi fisinya serta memandang hina Maria yang penuh dosa karena ia adalah seorang pelacur. Pastor mengatakan, bahwa Maria sebenarnya tidak butuh pastor melainkan harus ditangani oleh dokter jiwa. Puisi Nyanyian Angsa akan dianalisis menggunakan teori sosiologi sastra dengan memokuskan kajian pada aspek agama. Sosiologi sastra merupakan pendekatan terhadap sastra dengan mempertimbangkan segi-segi kemasyarakatan. Lebih lanjut Damono (1979: 2) mengatakan bahwa sosiologi sastra mencakup berbagai pendekatan, masing-masing didasarkan pada sikap dan pandangan teoritis tertentu, akan tetapi semua pandangan tersebut menunjukan kesamaan yaitu perhatian terhadap sastra sebagai lembaga sosial yang diciptakan sastrawan sebagai anggota masyarakat.

Kekuatan pendekatan sosiologis terhadap karya sastra terletak pada pandangan yang melihat sastra sebagai suatu hasil budaya yang diperlukan masyarakat. Karya sastra dibuat untuk mendidik masyarakat. Sastra merupakan media komunikasi yang mampu merekam gejolak hidup masyarakat dan mengabdikan diri untuk kepentingan masyarakat (Semi, 1993: 76). Sastra menyajikan kehidupan dan sebagian besar terdiri dari kenyataan sosial walaupun karya sastra meniru alam dan dunia subjektif manusia (Wellek dan Warren, 1993: 109). Luxemburg dkk (1989:23) mengemukakan bahwa sastra dapat dipandang sebagai suatu gejala sosial, sebab sastra yang ditulis pada kurun waktu tertentu langsung berkaitan dengan normanorma dan adat istihadat zaman itu. Sosiologi sastra memiliki beberapa aspek, seperti aspek sosial-budaya, aspek ekonomi, aspek agama, dan aspek pendidikan.

Menurut Damono (1979: 2-3) ada dua kecenderungan utama dalam telaah sosiologis terhadap sastra, yaitu: pertama, pendekatan yang berdasarkan pada anggapan bahwa sastra merupakan cermin proses sosial ekonomi. Pendekatan ini ada kaitannya dengan faktor-faktor di luar sastra. Sastra hanya akan berharga apabila dihubungkan dengan faktor-faktor di luar karya sastra. Kedua, pendekatan yang mengutamakan teks sastra sebagai bahan penelaahan. Teks dianalisis untuk 
mengetahui strukturnya yang kemudian digunakan untuk memahami gejala sosial yang ada di luar sastra. Berdasarkan uraian di atas maka puisi Nyanyian Angsa relevan bila dianalisis dengan menggunakan teori sosiologi sastra dengan penekanan pada aspek agama. Analisis sosiologi sastra dalam puisi ini ditekankan pada telaah yang menggunakan teks untuk melihat struktur dan gejala-gejala sosiologis yang ada di dalamnya.

\section{PEMBAHASAN}

Setiap karya sastra mengandung pesan baik disampaikan secara eksplisit atau implisit oleh pengarangnya. Karya sastra dikatakan berhasil ketika karya tersebut mendapat banyak tanggapan, apresiasi, telaah, dan kritikan dari pembacanya. Dengan kata lain, karya sastra itu berhasil ketika banyak orang yang membacanya. Kritik di dalam sebuah karya sastra salah satunya bisa tercermin melalui kehidupan sosial para tokoh di dalamnya, seperti aspek agama maupun budayanya. Puisi Nyanyian Angsa karya W.S Rendra akan dianalisi menggunakan teori sosiologi sastra dengan menganalisis secara mendalam pada kritik sosial terhadap tokoh utama dan tokoh sampingan, yakni seorang pastor yang memarjinalkan status Maria sebagai sorang pelacur. Agama bukan membawa sang pastor untuk bersikap bijaksana dalam memandang segala masalah.

Agama adalah suatu ajaran atau keyakinan yang menuntun manusia dalam berbuat kebaikan. Kata "agama" berasal dari bahasa Sansekerta, āgama yang berarti "tradisi". Sedangkan kata lain untuk menyatakan konsep ini adalah religi yang berasal dari bahasa Latin reigio dan berakar pada kata kerja re-ligare yang berarti "mengikat kembali". Maksudnya dengan bereligi, seseorang mengikat dirinya kepada Tuhan. Dalam Kamus Besar Bahasa Indonesia (2008:15) agama merupakan ajaran, sistem yang mengatur tata keimanan (kepercayaan) dan peribadatan kepada Tuhan Yang Mahakuasa serta tata kaidah yang berhubungan dengan pergaulan manusia dan manusia serta manusia dan lingkungannnya.

Puisi Nyanyian Angsa mengandung pesan dan kritik terhadap agama terlihat melalui alur dan penokohan tokoh Marai dan pastor. Agama idealnya membawa penganutnya ke arah yang lebih baik, namun Marai sebagai umat yang beragama Kristen malah mendapatkan perlakauan yang tidak baik dalam lingkungan sosialnya karena statusnya sebagai wanita malam. Agama dalam kajian ini diartikan sebagai sebuah ajaran yang dipegang oleh tokoh utama/Maria yang tidak mencerminkan sikap seseorang yang beragama, yang senantiasa bersabar dalam kondisi/keadaan ekonomi yang tidak mendukung. Agama merupakan tema sentral dalam kajian ini. Tokoh Maria dan pastor memiliki pandangan yang sama terhadap agama, karena agama tidak membawa tokoh-tokoh dalam puisi tersebut menuju sikap yang baik, yang tidak memandang dan menilai seseorang hanya dari keburukannya.

Agama sebagai ideologi pada tataran individu, etika berfungsi sebagai proses awal pembentukan indentitas. Konstruksi identitas akan memberikan kesadaran untuk mempercayai segala kebenaran yang disampaikan oleh suatu agama. Apabila seorang penganut agama mempunyai kesadaran tentang identitasnya dalam suatu agama, maka komitmennya pada agama tidak akan diragukan lagi (dalam Andrhy, 2012). Dengan kalimat lain, dapat dikatakan bahwa militansi seorang penganut agama berawal dari pembentukan identitas pada dirinya. Tradisi keagamaan selalu menunjukkan bahwa Tuhan tidak suka pada beberapa perilaku yang dianggap salah dan juga memberikan restu pada perilaku yang dianggap benar. Konsep ini 
juga memberikan pemahaman untuk memberikan penghargaan kepada pelaku agama, yang benar diberikan pahala sedangkan yang salah diberikan dosa. Identitas kelompok (agama) inilah yang menjadikan awal ideologisasi agama bagi pemeluknya. Hal ini tercermin dalam puisi Nyanyian Angsa, mengungkap kritik sosial melalui prilaku yang salah sebagai umat yang beragama.

$$
\text { Kritik sosial merupakan }
$$

pertimbangan, sanggahan, atau celaan terhadap kehidupan sosial seorang individu yang dinilai tidak sesuai dengan norma yang telah disepakati oleh sekelompok masyarakat pada suatu tempat, seperti yang dialami oleh Maria. Sebagai seorang penganut agama, idealnya Maria lebih bersabar dalam menghadapi hidup jika sudah melakukan suatu usaha. Namun, Maria menjadi seorang pelacur karena terdesak kemiskinan. Akibat dari pekerjaannya tersebut Marai menjadi diasingkirkan baik dari tempatnya bekerja atau oleh masyarakat pada umumnya. Kemiskinan bukanlah alasan untuk melakukan perbuatan dosa dalam konteks agama.

Hal ini dapat dilihat pada bait kelima.

Lalu pastor kembali bersuara:

"Kamu telah tergoda dosa."

"Tidak tergoda. Tapi melulu

berdosa."

"Kamu telah terbujuk setan."

"Tidak. Saya terdesak kemiskinan.

Dan gagal mencari kerja."

Berdasarkan kutipan di atas, terlihat bahwa tokoh Maria hidup di daerah perkotaan dan telah terbawa dalam kehidupan perkotaan yang individualis, yang tidak terlalu mementingkan pekerjaan yang halal (tidak melanggar norma agama) yang lebih dipentingkan adalah materi. Dengan kata lain, bahwa segala kehidupan di dunia ini bisa dibeli dengan uang. Perhatikan bait ketujuh.
Lalu ia berjalan ke belakang satu retoran.

Dari tong sampah ia kumpulkan sisa makanan.

Kemudian ia bungkus hati-hati

dengan daun pisang.

Lalu berjalan menuju ke luar kota.

Berdasarkan bait di atas terlihat bahwa tempat pelacuran sering kali tumbuh di daerah perkotaan seperti di Jakarta atau Yogyakarta, karena kebanyakan penghuni kota adalah orang-orang pendatang, yang tidak banyak saling mengenal satu sama lain. Karena salah satu faktor inilah maka tidak ada yang saling memperhatika, antar orang yang satu berprofesi sebagai guru ataukah pelacur. Siap yang tau. Selain itu, warga kota hanya memikirkan kepentingan duniawinya saja. Seakan-akan mereka hidup kekal di dunia. Namun, ketika fisik sudah tidak mampu menopang keinginan, maka seseorang akan mulai mengingat kematian, mulai mengingat Tuhannya. Seperti Maria yang ingin mengaku dosa saat keadannya tengah terpuruk. Hal ini dapat dilihat pada bait kelima.

\section{Maria Zaitun menjawabnya: \\ "Mau mengaku dosa." \\ "Tapi ini bukan jam bicara. \\ Ini waktu saya untuk berdo'a." \\ "Saya mau mati." \\ "Kamu sakit?" \\ "Ya. Saya kena rajasinga."}

Maria ingin mengaku dosa kepada pastor saat merasa sudah tidak ada lagi orang yang bisa menolongnya selain Tuhan. Kaum atheis memandang bahwa Tuhan adalah pelarian dari rasa sakit dan sedih. Artinya, bahwa manusia mengingat Tuhan saat keadannya tengah terpuruk. Namun, secara umum umat beragama memaknai agama/Tuhan sebagai sebuah kebutuhan hidup yang harus terpenuhi, bukanlah sebuah pelarian. Perhatikan bait kelima. 
Saya tak butuh tahu asal usul dosa saya.

Yang nyata hidup saya sudah gagal.

Jiwa saya kalut.

Dan saya mau mati.

Sekarang saya takut sekali.

Saya perlu Tuhan atau apa saja

untuk menemani saya."

Agama pada hakikatnya menuntun manusia untuk belaku selayaknya manusia, yang memiliki rasa simpati dan empati. Ketika seseorang telah menyakiti orang lain, maka seseorang tersebut juga akan merasakan rasa sakit dan begitu pula sebaliknya. Oleh karena itu, orang yang beriman tidak akan melakukan kesalahan/pelanggaran atau mengambil hak orang lain. Kembali ke hukum alam, bahwa menanam kebaikan maka akan berbuah kebaikan. Jika menanam padi maka yang dihasilkan adalah beras, bukan jagung.

Maria termarjinalkan dari lingkungan sosialnya merupakan buah dari pebuatnya. Meskipun pada kenyataannya warga kota pada umumnya tidak saling mempedulikan soal pekerjaan dan status sosial, akan tetapi masih ada orang tertentu yang tidak mengargai keberadaan Maria, seperti pastor, orang-orang di tempatnya berobat, dan orang-orang yang melihatnya di jalan. Mereka memandang hina Maria, baik dari tampilan fisik atau pekerjaannya karena sebagian besar orang-orang kota hidup mewah, seperti dilihat dari makanan, pakaian, dan fasilitas yang digunakannya. Sementara Maria datang dengan pakaian lusuh tanpa alas kaki, tanpa membawa tas atau sehelai pakaian ganti, tubuhnya yang bau anyir karena penyakitnya, yang mengambil sisa makannan dari tong sampah, tidak memiliki uang seperak pun dan denga status sebagai seorang pelacur.

Manusia sebagai anggota masyarakat memiliki kelas/golongan seperti golongan masyarakat yang intelek atau golongan/tokoh agama. Tokoh agama memiliki citra yang baik dalam masyarakat, tetapi tetap ada pengecualiannya yakni ada tokoh agama yang melakukan tindak kejahatan atau tidak belaku adil dalam masyarakat, seperti yang terjadi pada pastor ketika menghadapi Maria. Perhatikan bait kelima berikut.

Dan muka pastor menjadi merah padam.

Ia menuding Maria Zaitun.

Mendengar ini pastor mundur dua

tindak.

Mukanya mungkret.

Akhirnya agak keder ia kembali

bersuara:

"Ара kати - mm - kuри-kupu

malam?"

"Saya pelacur. Ya."

Keadaan Maria begitu terpuruk karena sebagai umat yang beragama Maria telah berbuat dosa, tetapi ia telah meyadari kesalahnnya tersebut dan bertobat. Meskipun seorang pelacur dipandang hina oleh masyarakat namun hanya Tuhan yang tidak membeda-bedakan umatnya baik dari status sosilannya. Tuhan mahapemaaf selama manusia bersunggu-sungguh dalam bertobat. Perhatikan bait enam belas berikut.

Ia jumpai bekas-bekas luka di tubuh pahlawannya.

Di lambung kiri.

Di dua tapak tangan.

Di dua tapak kaki.

Maria Zaitun pelan berkata:

"Aku tahu siapa kamu."

Lalu menebak lelaki itu dengan pandang matanya.

Lelaki itu menganggukkan kepala:

"Betul. Ya."

Perhatikan juga bait tujuh belas berikut.

(Malaekat penjaga firdaus wajahnya jahat dan dengki dengan pedang yang menyala tak bisa apa-apa. 
Dengan kaku ia beku.

Tak berani lagi menuding padaku.

Aku tak takut lagi.

Sepi dan duka telah sirna.

Sambil menari kumasuki taman

firdaus

dan kumakan apel sepuasku.

Maria Zaitun namaku.

Pelacur dan pengantin adalah saya.)

Agama memberi ketenangan bagi setiap pemeluknya, perhatikan bait ketujuh belas di atas. Tujuan beragama adalah mencapai kebahagiaan baik di dunia maupun di akhirat. Agama memberi pandangan dunia kepada manusia karena ia senantiasa memberi penerangan kepada dunia dan juga kedudukan manusia di dalamnya. Manfaat hidup beragama adalah apabila terjadi perubahan atas diri seseorang ke arah yang lebih baik. Setiap jiwa akan kembali kepada penciptanya, karena sebagai penganut agama Maria merasa takut ketika tengah mengadapi sakit karena mengingat dosa yang telah diperbuatnya dan saat itu juga ia mengingat Tuhannya. Ketika Maria terlepas dari beban dosa, maka Maria merasakan damai mengadapai segala cobaan hidup.

\section{PENUTUP}

Kritik sosial merupakan pertimbangan, sanggahan, atau celaan terhadap kehidupan sosial seorang individu yang dinilai tidak sesuai dengan norma yang telah disepakati oleh sekelompok masyarakat pada suatu tempat. Sebagai seorang penganut agama, idealnya seseorang akan lebih bersabar dalam menghadapi cobaan hidup dan kemiskinan bukanlah alasan untuk melakukan perbuatan dosa dalam konteks agama. Meskipun seorang pelacur dipandang hina oleh masyarakat namun hanya Tuhan yang tidak membeda-bedakan umatnya baik dari status sosilannya. Tuhan mahapemaaf selama manusia bersunggu-sungguh dalam bertobat.

Agama memberi ketenangan bagi setiap pemeluknya. Tujuan beragama adalah mencapai kebahagiaan baik di dunia maupun di akhirat. Agama memberi pandangan dunia kepada manusia karena ia senantiasa memberi penerangan kepada dunia dan juga kedudukan manusia di dalamnya. Manfaat hidup beragama adalah apabila terjadi perubahan atas diri seseorang ke arah yang lebih baik. Agama bukanlah pelarian dari rasa takut, tetapi agama adalah sebuah kebutuhan dan setiap jiwa akan kembali kepada penciptanya.

\section{DAFTAR PUSTAKA}

Aminuddin. 2011. Pengantar Apresiasi Karya Sastra. Bandung: Sinar Baru Algensindo.

Damono, Sapardi Djoko. 1979. Sosiologi Sastra Sebuah Pengantar Ringkas. Jakarta: Pusat Pembinaan dan Pengembangan Bahasa. Departeman Pendidikan dan Kebudayaan.

Departemen Pendidikan Nasional. 2008. Kamus Besar Bahasa Indonesia Pusat Bahasa. Jakarta: Balai Pustaka.

Luxemburg, Jan Van dkk. 1989. Pengantar Ilmu Sastra. Terjemahan Oleh Dick Hartoko dari Inleiding De Literatuur Watenschaf. Jakarta: PT Gramedia.

Semi, M. Atar. 1993. Metode Penelitian Sastra. Bandung: Angkasa.

Tim Penyusun Kamus Pusat Bahasa, 1996. Kamus Besar Bahasa Indonesia. Jakarta: Balai Pustaka.

Wellek, Rene dan Austin Warren. 1993. Teori Kesusastraan. Terjemahan Melani Budianta dari Theory of Literature (1997). Jakarta: PT Gramedia 